Pamiętnik Literacki 2021, 2, s. 65-77

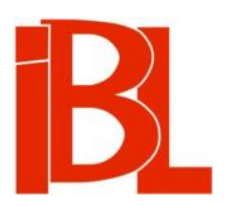

\title{
Wolter, Diderot, Marivaux, albo klasycyzm, sentymentalizm, rokoko w teatrze
}

\author{
Marek Dębowski
}


Pamiętnik Literacki CXII, 2021, z. 2, PL ISSN 0031-0514

DOI: $10.18318 / \mathrm{pl} .2021 .2 .5$

MAREK DĘBOWSKI Uniwersytet Jagielloński, Kraków

\section{WOLTER, DIDEROT, MARIVAUX, ALBO KLASYCYZM, SENTYMENTALIZM, ROKOKO W TEATRZE}

W bodaj najbardziej znanej książce Teresy Kostkiewiczowej Klasycyzm, sentymentalizm, rokoko, wydanej przeszło 40 lat temu, na samym końcu rozważań znajdujemy apel autorki o prowadzenie badań szczegółowych nad rola indywidualności twórczych, „które z żadnym kierunkiem nie wiązały się całkowicie i jednoznacznie, natomiast całym swoim dorobkiem brały najżywszy udział w procesie kontaktowania ze sobą i konfrontowania możliwości literackiego działania, przewidzianych w obrębie różnych prądów" ${ }^{1}$. Kostkiewiczowej chodzi głównie o dwu autorów: Franciszka Zabłockiego, „który stał się wybitnym poszukiwaczem form na polu osiemnastowiecznego dramatu polskiego, śmiało sięgającym po wielorakie inspiracje i techniki dramatyczne bliskie zarówno klasycyzmowi, jak i literaturze sentymentalnej oraz rokoku [...]”, i Juliana Niemcewicza, „służącego doświadczeniem różnym prądom, jakkolwiek najbliższego sentymentalizmowi”2.

Po upływie czasu możemy powiedzieć, że apel spotkał się z odzewem. Przykładowo: w latach dziewięćdziesiąych ubiegłego stulecia ukazało się 5-tomowe wydanie krytyczne Teatru Franciszka Zabłockiego, opracowane przez Janinę Pawłowiczowa ${ }^{3}$. Jest to jak dotąd najobszerniejsze studium naukowe poświęcone temu autorowi. Justyna Łukaszewicz wydała w roku 2006 rozprawę Dramaty Franciszka Zabłockiego jako przekłady i adaptacje, omawiającą źródła, z których czerpał nasz najlepszy dramatopisarz oświeceniowy ${ }^{4} . Z$ kolei spuścizna poetycka Niemcewicza doczekała się świetnej monografii autorstwa Grzegorza Zająca pt. Czuły weredyk. Twórczość poetycka Juliana Ursyna Niemcewicza ${ }^{5}$.

Dzieła obu wspomnianych autorów - jak wiadomo - często grano w Teatrze Narodowym w Warszawie, przed rozbiorami i po nich. Jednak dramatopisarstwo stanowi w książce Kostkiewiczowej tylko niewielką część przykładów, które ilustrują kształtowanie się i jakościowe zmiany funkcjonowania polskiej literatury w dobie oświecenia, natomiast spojrzenie teatrologiczne, czyli los przedstawień klasycznych, sentymentalnych bądź rokokowych na scenie, nie jest celem badaczki. Dlatego proponuję, zgodnie $\mathrm{z}$ tytułem, zwrócić uwagę na trzech autorów, których sztuki

1 T. Ko s t ki e w i c z ow a, Klasycyzm, sentymentalizm, rokoko. Szkice o pradach literackich polskiego oświecenia. Warszawa 1975, s. 462.

Ibidem.

F. Zabłocki, Teatr. Oprac. J. Pawłowi c zowa. T. 1-5. Wrocław 1994-1996.

J. Łuka s z ew i c z, Dramaty Franciszka Zabłockiego jako przekłady i adaptacje. Wrocław 2006.

G. Zaj ą c, Czuły weredyk. Twórczość poetycka Juliana Ursyna Niemcewicza. Kraków 2015. 
były grane dla polskiej publiczności w teatrze stołecznym i na prowincji i którzy są do dzisiaj uznawani za reprezentantów trzech głównych XVIII-wiecznych prądów literacko-artystycznych. Pozwoli to, mam nadzieję, na postawienie kilku nowych akcentów w refleksjach na temat użyteczności pojęć stosowanych do klasyfikacji ówczesnej twórczości teatralnej.

W części Klasycyzm książki Kostkiewiczowej, odnośnie do form artystycznych literatury, czytamy: „rozważanie wszelkich kwestii konkretnych zasad poetyki klasycystycznej możliwe jest jedynie w perspektywie rozróżnień gatunkowych" ${ }^{6}$. Zgodnie $z$ hierarchią klasycznych gatunków - na pierwszym miejscu pojawia się w związ$\mathrm{ku} z$ tym tragedia.

W XVIII-wiecznej konstelacji autorów tragicznych najjaśniejsza gwiazdą był z pewnością Wolter. W jego epoce uznawano go za największego pisarza nie dlatego, iż tworzył powiastki filozoficzne, naukowe rozprawy i świetne artykuły do Encyclopédie, lecz dlatego, że tworzył tragedie ${ }^{7}$. Jako zwolennik starożytników - jego głównym antagonistą był nowożytnik Pierre de Marivaux - w słynnym, ciągnącym się z różnym nasileniem od końca XVII wieku sporze starożytników z nowożytnikami Wolter pragnie przebudować i odnowić „monumentalną budowlę, jak nazywano tragedię klasyczna. Jednocześnie broni, ale nie w imię tradycji, lecz w imię rozumu i natury, mądrych reguł teatru. Po raz pierwszy wykłada swe racje w przedmowie do debiutanckiej tragedii Edyp (Oedipe) ${ }^{8}$, która odniosła wielki sukces (45 przedstawień) w Comédie-Française w 1718 roku. Od tego momentu Wolter dąży do zreformowania tragedii w dwu kierunkach. Pierwszy to podniesienie na wyższy poziom widowiskowości owego gatunku. Atrakcyjność wizualna tragedii klasycznej granej w Comédie-Française jest na początku XVIII wieku nikła. Od powstania pierwszej publicznej sceny francuskiej w 1680 roku w przedstawieniach tragediowych ustalił się styl gry deklamacyjnej, będący swoistym laboratorium retoryki i pięknej wymowy, gry, której towarzyszyły dekoracje bardzo skromne i niekoniecznie powiązane $\mathrm{z}$ treścią sztuki. Wolter, po dłuższym pobycie w Anglii w latach dwudziestych XVIII stulecia, gdzie oglądał spektakle szekspirowskie, stara się wpłynąć na zmianę utrwalanej od 100 lat estetyki przedstawien tragediowych we Francji. To zagadnienie, niezwykle interesujacce, opisał w 1800 roku Wilhelm von Humboldt, przekonując, że publiczność chodziła na tragedie Woltera w XVIII wieku dlatego, iż fascynowały ja przede wszystkim role grane przez wielkie aktorki, np. przez Contat, Raucourt czy Clairon, którą chciał zaprosić do Warszawy jej wielbiciel Stanisław August, i świetnych aktorów tragicznych, takich jak Lekain, Larive, a później Talma9 ${ }^{9}$

Drugi kierunek reformowania tragedii przez Woltera - to nasycanie treści sztuk ideologią oświecenia ${ }^{10}$. Kilkanaście tragedii, które tworzył przez 60 lat od roku 1718

Kostkiewiczowa, op. cit., s. 107.

Zob. J. Tru ch et, La Tragédie classique en France. Paris 1975, s. 161-164.

V Volta ir e' a Préface d',OEdipe” znajduje się w drugim wydaniu tragedii z 1730 roku. Idee dotyczące tragedii XVIII-wiecznej autor rozwija znacznie szerzej w Dissertation sur la tragédie ancienne et moderne (Rozprawa o starożytnej i współczesnej tragedii), która ukazała się drukiem jako przedmowa do tragedii Semiramis (Sémiramis, 1748).

9 W. v o n $\mathrm{H}$ u m b old t, Uwagi Niemca o sztuce scenicznej francuskich aktorów tragicznych. Przekł., wstęp, oprac., przypisy M. Dę bowski. Gdańsk 2010.

10 Zob. M. D ę b ow ski, Z problematyki tragedii klasycznej $w$ XVIII wieku, albo Jak Wolter zastapit 
(Edyp) do roku 1778 (Irène), świadczy o konsekwencji Woltera w prezentowaniu racjonalnych poglądów we wszystkich dziełach teatralnych. Wszystkich, gdyż Wolter napisał też - jak wiemy - trzy komedie poważne: L’Enfant prodigue, Nanine, L'Ecossaise, z których pierwsza, popularna u nas pt. Syn marnotrawny, zrobiła szczególną kariere po jej spolszczeniu wierszem przez Stanisława Trembeckiego. Tragedie Woltera stanowia, $z$ jednej strony, ilustracje jego refleksji filozoficznej, znanej także $z$ innych dzieł, $z$ drugiej zaś - budują fundamenty myśli XVIII-wiecznej w sensie ogólnym. Dotyczą bowiem świadomości oświeceniowej w zakresie religijności, systemu politycznego oraz życia rodzinnego. Tworzenie nowych relacji w tych trzech ogromnych obszarach aktywności człowieka stało się - jak wiemy podstawowym zadaniem niemal wszystkich filozofów oświecenia, zadaniem, którego eksplikację odnajdujemy głównie na kartach Encyclopédie. Wolter podobne zadanie, czyli tworzenie nowej świadomości, postawił również tragedii, rezygnując już w Edypie - z metafizyki, ściślej: rezygnując z siły wyższej, której działanie zawsze skazuje człowieka na porażkę i której pobudek nie jest on w stanie pojać. Skoro bowiem człowiek oświecenia powinien być racjonalny i ma wręcz obowiązek zrozumieć swój los, poeta musi zastąić owo fatalne przeznaczenie i wprowadzić coś, co zastępuje transcendencje, po to, by jednak ostateczne rozwiązanie konfliktu miało charakter tragiczny, czyli by nieuchronnie prowadziło do śmierci. Jak to zrobić? Oto co przynosi nam lektura dzieł teatralnych Woltera.

Pierwszy z sygnalizowanych wielkich tematów - walka z nietolerancją i obskurantyzmem religijnym - staje się motorem napędowym akcji w kilku tragediach, najwyraźniej zaś w dwu: Mahomet, albo Fanatyzm (Le Fanatisme ou Mahomet le Profète, 1742) i Zaira (Zaïre, 1732). W Mahomecie Wolter zarysowuje skrajnie uproszczona ideę islamu, w drugiej chrześcijaństwa. Mahomet Woltera - w porównaniu z postacią historycznego proroka - jest fanatykiem o skłonnościach kryminalnych, który w odruchu prymitywnej zemsty na szejku Zopirze więzi jego dwoje dzieci, by następnie otruć mu córkę Seidę i doprowadzić do samobójstwa jego syna Palmira. Oprócz bohaterów indywidualnych występują tu także, na zasadzie bohatera zbiorowego, sfanatyzowane tłumy muzułmanów. Karykaturalny wizerunek Mahometa, na którego temat filozofowie mieli skądinąd raczej dobre zdanie, próbuje pomóc w zilustrowaniu myśli Woltera dotyczącej odruchów zbiorowości, które zawsze łakna krwi, dowodzone zaś przez charyzmatycznych kryminalistów skazują się na zgubę.

W Zairze Wolter atakuje chrześcijaństwo. W tej tragedii główne postaci są jednak sympatyczniejsze i psychologicznie bardziej skomplikowane. Niewykluczone, iż w tym przypadku poeta, może mimowolnie, wyposażył swych bohaterów we wrażliwość uczuciową i religijną, którą znał przecież o wiele lepiej niż wrażliwość muzułmańską. Tytułowa bohaterka tragedii Zaira jest córką starego rycerza krzyżowego, ostatniego potomka chrześcijańskich królów Jerozolimy. Oboje są więźniami młodego sułtana Orozmana, który kocha się w Zairze i pragnie ją pojać za żonę. Zaira także go kocha i też chce go poślubić, ale jako osoba jeszcze nieochrzczona waha się, jaką religię wybrać: czy religię ukochanego, czy wiare przodków? Brat Zairy pisze do niej płomienne listy z Francji, by jak najszybciej zdecydowała się na

fatum ideologia. W zb.: Dtugie trwanie. Różne oblicza klasycyzmu. Red. R. Dą b row s ki, B. D op a r t. Kraków 2011. 
chrzest. Listy przejmuje Orozman i nie wiedząc, że są od brata, podejrzewa Zairę o zdradę. W szale zazdrości zabija ją, a gdy się dowiaduje prawdy, popełnia samobójstwo. Podobieństwo tej tragedii do Szekspirowskiego Otella jest uzasadnione. Sam Wolter też się go nie wypierał, choć zasadniczy wydźwięk jego tragedii nie dotyczy cierpień zazdrości. Wybór właściwej religii przez bohaterkę, którą zmuszają do tego okoliczności jest, zdaniem Woltera, pozbawiony sensu. Wszystkie religie, co wiemy również np. z powiastki Kandyd, czyli Optymizm, są bowiem podobne do siebie i wszystkie bez wyjątku pozbawiają człowieka jasności myślenia.

Drugi temat, $z$ lubością uprawiany przez Woltera w tragedii, to walka o sprawiedliwy system polityczny, czyli walka z tyranią i absolutyzmem. W konkretnych okolicznościach panowania Ludwika XV było zrozumiałe, iż widzowie domyślą się, że chodzi o walkę $\mathrm{z}$ francuską monarchią. W tragediach Brutus (1731) i Śmierć Cezara (La Mort de César, 1735) został ukazany, w sposób skądinąd utopijny, zarys monarchii sprawiedliwej, oświeconej i liberalnej, odległej zarówno od państwa represyjnego, jak i od rewolucyjnego oportunizmu. W obu utworach odnajdujemy elementy antynomiczne, np. pacyfizm równoległy z szowinizmem, co zreszta przypomina nam, że niekiedy refleksja polityczna Woltera jest mało jasna. Jego tragedia Meropa (1742) to modyfikacja tragedii pod takim samym tytułem włoskiego poety Scipionego Maffeiego. W roku 1779 Meropa została przetłumaczona na polski przez ojca pijara Augustyna Orłowskiego i była to pierwsza tragedia klasyczna zrealizowana na scenie Teatru Narodowego w 1792 roku, czyli w czasach drugiej dyrekcji warszawskiej Wojciecha Bogusławskiego. Meropę grano, co już kiedyś opisałem $^{11}$, przede wszystkim jako tragedię polityczną, która w listopadzie 1792, w momencie gdy do Warszawy zbliżały się wojska rosyjskie, miała przypomnieć Polakom, czym różni się represyjna tyrania Katarzyny II od oświeconej monarchii konstytucyjnej Stanisława Augusta. Wątek tragediowy ułożony przez Woltera nadawał się do takiej okolicznościowej, polskiej interpretacji (przedstawianej w 1792 roku przez Bogusławskiego), zwłaszcza zaś konflikt między Egistosem, synem Meropy, a uzurpatorem Polifontem, który zdetronizował i zmasakrował jego ojca. Rozwiązanie tragedii, po zabiciu tyrana przez Egistosa, konkluduje bowiem deklaracja polityczna zwycięzcy, który przyrzeka, że Messyna za rządów jego oraz Meropy, stanie się krajem równych praw dla wszystkich bez wyjątku, w czym można się było dopatrzeć nawiązania do Konstytucji 3 Maja, której pierwszą rocznicę uroczyście obchodzono w Warszawie 6 miesięcy wcześniej. Tendencyjność tej tragedii wystawionej przez Bogusławskiego jeszcze w wolnej Rzeczypospolitej jest bardziej widoczna w zestawieniu z wersją w tłumaczeniu Jana Drozdowskiego, graną kilka lat później (w 1803 roku), z której zniknęły wszelkie aluzje polityczne.

Perypetie i polityczne qui pro quo w Meropie, dziś trudne w odbiorze, przysłaniają wszakże w tej sztuce Woltera coś, co można by uznać za jeden $z$ oryginalniejszych elementów jego odnowy tragedii klasycznej. Myślę o trzecim wielkim temacie ideologii oświeceniowej - reformie życia społeczno-rodzinnego. Ów temat, w formie do pewnego stopnia zideologizowanej, bliskiej późniejszym postulatom dramy mieszczańskiej Denisa Diderota, Pierre’a Beaumarchais'go i Louisa-Sébastiena

11 M. D ę bow s ki, Trzy szkice o aktorstwie tragicznym $w$ dobie oświecenia i klasycyzmu. Kraków 1996. 
Merciera, pojawia się u Woltera już w 1736 roku, ale nie w tragedii, lecz w komedii poważnej Syn marnotrawny. Miłość rodzicielska, pełna tkliwości i wyrozumiałości, choć niewykluczająca brutalnej siły, jest tu uczuciem, którego wcześniej teatr francuski nie znał. Pisarze młodsi o pokolenie uchwycili przesłanie Woltera jako wzór estetyczny dla nowej, postępowej dramaturgii i promowali je szeroko. W polemice Beaumarchais'go z tragediami klasycznymi z 1767 roku, zamieszczonej w szkicu o dramacie, czytamy:

Jeśli ktoś jest [...] barbarzyńcą lub zwolennikiem klasyków, trzeba mu uświadomić, [...] że wiele scen z Syna marnotrawnego, że cała Nanine [...] sprawiły, iż znajdujemy upodobanie we wzruszających obrazach rodzinnego nieszczęścia, mających tym potężniejszy wpływ na nasze serca, że nieszczęścia takie zagrażają nam $z$ bliska. [...] Jeśli nasze serce wzruszają postaci tragediowe, to nie dlatego, iż są herosami czy królami, lecz dlatego, iż są ludźmi nieszczęśliwymi. Czy to królowa Messyny wzrusza mnie w postaci Meropy? Nie, to matka Egistosa: wyłącznie natura ma prawo do mego serca! ${ }^{12}$

Beaumarchais słusznie docenia u Woltera ten właśnie rodzinny element uczuciowości, którego zasadniczo brak w tragedii klasycznej. Stanowi on bowiem fundament sentymentalizmu. Wolter też z pewnością podzielał opinię, że problemy monarchii, tyranii czy wojny nie wyczerpują pola zainteresowań miłośników tragedii, i po sukcesie scenicznym Syna marnotrawnego napisał Meropę, do której, oprócz wcześniej omawianej walki o władzę, wprowadza równolegle wątek miłości matczynej odwzajemnianej przez syna. Katastrofa tej tragedii następuje w sytuacji, która jest godna wyobraźni Sigmunda Freuda. Egistos wpada do świątyni Hymena i widzi w objęciach tyrana Polifonta matkę, zniewoloną do małżeństwa szantażem. Zatrzymany przez straż, która ma go zgładzić, wyrywa się do matki, ale to ona pierwsza nadludzką siłą rozrywa ściskające ją ramiona uzurpatora i zasłania syna swym ciałem. Egistos może wówczas uciec straży i zabić niedoszłego ojczyma. Meropa, napisana w 1742 roku, jest już z pewnością tragedią realizująca jeden $z$ najważniejszych postulatów moralnych oświecenia, który dotyczy nowych relacji rodzinnych. Będzie on urzeczywistniony przede wszystkim w późniejszej o 20 lat dramie mieszczańskiej. Można tu wymienić np. Syna naturalnego (Le Fils naturel), Oćca dobrego (Le Père de la famille), Matkę dobra (La Mère confidente) itd., których tytuły mówią same za siebie i przypominają oświeconym, że dobro człowieka zaczyna się od dobra rodziny.

Opinia o Wolterze jako twórcy klasycznym pozostaje jednak do dzisiaj niezmieniona. Zdzisław Libera podaje:

Jako twórca tragedii osnutych na motywach starożytnych, narodowych i wschodnich Wolter dbał zawsze o to, by odpowiadały one wymaganiom smaku klasycznego w zakresie formy, stylu i języka ${ }^{13}$.

Nie ma w tym zdaniu słów „ethos” (charakter postaci) albo „dianoia” (sposób myślenia), gdyż te składniki tragedii (w sensie arystotelesowskim) nie są już u Woltera klasyczne.

Kostkiewiczowa pisze, że sentymentalizm polski pojawia się „po raz pierwszy w działalności literackiej tłumaczy i adaptatorów - często anonimowych - dramy miesz1964, s. 151. Jeśli nie zaznaczono inaczej, wszystkie tłumaczenia z języka francuskiego - M. D. 
czańskiej"14. Wśród tytułów dram granych na scenie warszawskiej po ponownym otwarciu Teatru Narodowego w 1774 roku znajduje się także bardzo ważna sztuka Diderota Ociec dobry, która encyklopedysta napisał w 1758 roku i która była regularnie wystawiana w Comédie-Française od 1761 roku, stając się jego jedynym rzeczywistym sukcesem teatralnym. Jeszcze w 1769 roku Diderot wspominał w liście do Sophie Volland: „na widowni było tyleż mokrych chusteczek do nosa, co widzów; jeszcze trzy takie sztuki jak ta, a tragedia zostanie zamordowana"15. Oćca dobrego przełożył Zabłocki, warszawski teatr zaś dał premierowe przedstawienie w styczniu 1782. Dzięki badaniom Georges’a Benrekassy znamy powiązania istniejące między słynną comédie serieuse (komedią poważna) z 1758 roku a encyklopedycznym hasłem Jouissance (Rozkosz) z 1762 roku ${ }^{16}$, które - jak wiadomo - zredagował osobiście Diderot. Hasło to jest $z$ pewnościa pierwszą na gruncie europejskim próbą konceptualizacji seksualności ludzkiej i pierwszym wykazaniem różnicy w pojmowaniu seksualności przez kobietę i mężczyznę. W Oćcu dobrym nauki przedmałżeńskie udzielane przez pana d'Ormesson (u Zabłockiego: Dobrucki, „ociec dobry”) córce Cecylii nie pozostawiają żadnych wattpliwości, iż mamy do czynienia z zalążkowym stadium „ideologizacji moralności seksualnej mieszczan” 17 , która rozwinie się w odpowiedni artykuł Jouissance w Encyclopédie. Zabłocki znał prawdopodobnie następstwo czasowe obu tekstów, gdyż w tłumaczeniu wyciąga $z$ tego konsekwencje. W scenie 2 aktu II jest w pewnym sensie odważniejszy niż Diderot. Ostatnie dwa zdania $\mathrm{z}$ owej słynnej lekcji wychowania seksualnego brzmią: pierwsze w wiernym przekładzie Zabłockiego - „Cecylio, wspomnij sobie życie twej matki; możesz być słodsze życie od życia kobiety, która strawi dzień cały na pełnieniu obowiązków żony bacznej, czułej matki, pani łaskawej” ${ }^{18}$; drugie zdanie Diderota - „Cóż za temat do subtelnych rozmyślań unosi w sercu swoim, oddalając się wieczorem na spoczynek" ${ }^{19}$, Zabłocki tłumaczy natomiast: „Ileż ona uwag rozkosznych nie wnosi w sercu swoim na łoże, gdy wieczorem spoczywać idzie?”20, doprecyzowując jakby magiczną i oczyszczającą moc łóżka dzielonego przez kochających się małżonków. Oćca dobrego - o ile wiemy - zagrano wtedy w warszawskim teatrze tylko jeden raz. Nie znamy powodów decyzji o wstrzymaniu przedstawień. Ewa Rzadkowska przywołuje ogólne okoliczności polityczne lat osiemdziesiątych XVIII wieku ${ }^{21}$. Zbigniew Raszewski (w sposób bardziej wyważony) stawia hipotezę, iż król chyba w ogóle nie wyrażał dobrego zdania o repertuarze poczatku lat osiemdziesiatych (nie tylko z powodu Oćca dobrego), gdyż drobna i średnia szlachta, słowem: sarmaci, na któ-

Kostkiewiczowa, op. cit., s. 199.

D. Did e r ot, Pisma estetycznoteatralne. Przekł., wstęp, oprac. M. D ę b ow s ki. Gdańsk 2008, s. 10.

G. B e n r e k a s s a, L'Article „Jouissance” et l'idéologie érotique de Diderot. „Dix-huitième Siècle” 1980, $\mathrm{nr} 12$.

Ibidem, s. 30.

D. Did e r o [!], Ociec dobry. Komedyja $w$ pięciu aktach. [Przeł. F. Zabł o cki]. Warszawa 1789, s. $46-47$.

D. D i d e r o t, Le Père de famille. Cyt. za: M. D ę b ow s ki, Francuskie konteksty teatru polskiego $w$ dobie oświecenia. Kraków 2001, s. 100.

Did e r o [!], op. cit., s. 47. Zob. też Za bło c ki, op. cit., t. 2 (1995), s. 32.

E. Rza d k ow s ka, „Encyklopedia” i Diderot $w$ polskim oświeceniu. Wrocław 1955, s. 153. 
rych punkcie król miał - jak pisze Raszewski - „coś w rodzaju obsesji” ${ }^{22}$, nie była w tym repertuarze dość mocno krytykowana. Nam z kolei wydaje się, że ukazanie przez encyklopedystę w dramie Ociec dobry zamkniętego, prywatnego świata człowieka, w którym istota spraw polega na budowaniu wzajemnego porozumienia i zaufania wśród członków rodziny, a także podniesienie przez francuskiego pisarza tej problematyki do rangi najważniejszego składnika nowej mieszczańskiej ideologii musiały wzbudzić niechęć Stanisława Augusta z czysto osobistych powodów ${ }^{23}$. Można też - w przypadku Diderota - zapytać o cenzurę religijną. Wprawdzie, jeśli chodzi o jego dramaty, nie atakowano wprost bezbożności, ale encyklopedystów łatwo kojarzono $\mathrm{z}$ libertynami. Ci zaś byli często obiektami wręcz histerycznych refutacji autorów, wśród których „duchowni stanowili zdecydowaną większość” - jak pisze Jerzy Snopek w ksiażce o dziejach libertynizmu w Polsce ${ }^{24}$.

Ociec dobry został wydany we Francji w podobnej formie do wcześniejszej o rokeksperymentalnej sztuki Syn naturalny, nb. granej bez żadnego powodzenia. Obie natomiast były opatrzone przedmowami. Syn naturalny pojawił się w druku wraz z Rozmowami o „Synu naturalnym” (Entretiens sur „Le Fils naturel”) (trzy rozmowy), natomiast Oćca dobrego poprzedzała rozprawa O poezji dramatycznej (Discours sur la poèsie dramatique). Obie refleksje Diderota zostały przez krytykę paryską potraktowane poważnie, jako próby zdefiniowania nowego gatunku dramatycznego, mającego być konkurencją dla tragedii. „Correspondance littéraire, philosophique et critique", najbardziej prestiżowe czasopismo europejskie, prenumerowane przez wszystkie koronowane głowy Europy (w tym, oczywiście, przez Stanisława Augusta Poniatowskiego), podniosło w dniu 1 III 1757, piórem redaktora naczelnego barona Friedricha Melchiora Grimma, zasługi Diderota do rangi „absolutnego mistrza teatru"25. Współcześnie sądzi się, że sztuki teatralne o tematyce sentymentalnej (np. tragédie domestique 〈tragedia domowa〉, tragédie bourgeoise 〈tragedia burżuazyjna〉, comédie larmoyante (komedia łzawa〉) paryska krytyka zaczęła zauważać właśnie po dyskusjach o obu tekstach teoretycznoteatralnych redaktora Encyclopédie ${ }^{26}$. On sam też był przekonany, że stworzył dla teatru coś, co - jak napisał do Volland „zamorduje tragedię". A jednak wśród radykalnych opinii Diderota o francuskiej tragedii znajdujemy również takie, które wywołują wrażenie niekonsekwencji filozofa. W obu tekstach teoretycznych Diderot powraca do reguły trzech jedności, kamienia węgielnego klasycznej konstrukcji dramatycznej. Ku zdziwieniu czytelnika nie zwalcza jej: „Niełatwo przestrzegać praw trzech jedności, ale są to prawa rozsądne", przekonuje swego interlokutora Dorval w Rozmowie pierwszej27. Rozmówca Ja przyznaje mu rację, choć dopiero po dłuższej argumentacji, gdyż dalsze wywody wskazują na to, iż Arystotelesowska reguła zalecająca zamknięcie zdarzeń

Z. Ra s z e w s k i, Teatr Narodowy w latach 1779-1789. W zb.: Teatr Narodowy w dobie oświecenia. Księga pamiatkowa sesji poświęconej 200-leciu Teatru Narodowego. Red. nauk. E. Heis e, K. Wierzbicka-Michalska. Wrocław 1967, s. 66. Król, za pośrednictwem Grimma, zwracał się kilkakrotnie do Diderota z propozycją wymiany korespondencji na tematy filozoficzne. Diderot zawsze grzecznie odmawiał. 
dramatycznych w jednolitej akcji dziejącej się w jednym miejscu w krótkim czasie jest dla Diderota istotna wyłacznie z praktycznego punktu widzenia. Encyklopedysta ironizuje:

W małych teatrach, takich jak nasze, cóż ma myśleć rozsądny człowiek, kiedy słyszy, jak dworzanie, świadomi tego, że ściany mają uszy, knują spisek przeciw władcy w tym samym miejscu, w którym przed chwila radził się ich w sprawie największej wagi - oddania swej cesarskiej władzy? Skoro osoby pozostaja, widz mniema, że widocznie odchodzi miejsce ${ }^{28}$.

Czy w innych warunkach technicznych funkcjonowania widowisk w XVIII wieku Diderot zmieniłby swą opinię o rozsądnych „prawach trzech jedności”? Tego się nie dowiemy, bo zmiany techniczne, np. w Comédie-Française, następuja około 1830 roku (tzw. inscenizacja romantyczna), ale możemy zaryzykować pewną paralelę związaną z przywołanymi tu w akapicie o Wolterze składnikami tragedii według Arystotelesa. Otóż u Diderota, inaczej niż u Woltera, forma, styl i język dramatów nie mają już nic wspólnego z klasycyzmem.

Marivaux, pomimo zróżnicowanej twórczości, jest powszechnie uznawany za reprezentanta prądu rokokowego w literaturze. Złożyły się na tę opinię przede wszystkim jego komedie. Wybitny badacz XVIII wieku Jean Sgard stwierdza:

Marivaux daje nam odczuć okrucieństwo życia i poezję snu; komediopisarstwo [twórcy] przywodzi na myśl, że życie jest grą, której znaczenie nam umyka, a zadaniem poety jest wyrażenie jej wdzięku i ruchu. Wybiera on ulotność i na tym opiera sie jego sztuka prawdziwie rokokowa: zachwyt chwila, ruch istnienia w momencie powstania, nietrwałość, to mu wystarcza; poryw dobroci, albo dumy, gorliwość życia i kochania, wyznanie cierpienia lub bezczelność, wszystko, co nas porusza, jest improwizowane na naszych oczach. Ten nieruchomy czatownik nigdy się nie myli: $z$ uwagą oddając formę i melodię naszej egzystencji, nie udziela żadnej lekcji; wiernie, uczciwie wykreśla zawiłości naszych iluzji ${ }^{29}$.

Libera, w tym samym mniej więcej czasie co Sgard, tak napisał o istocie stylu rokoko:

Szukać go należy we wdzięcznych komediach Marivaux, które przemawiają dyskretnym humorem, oryginalnością pomysłów i mistrzostwem artystycznym. Jego Igraszki trafu i miłości, urocza komedia pełna ironii i dowcipu, oddycha atmosfera życia salonowego i daje wyobrażenie o poecie, od którego nazwiska wywodzi się odmiana stylu komediowego ${ }^{30}$.

Na przełomie lat sześćdziesiątych i siedemdziesiątych XX wieku, w związku z obchodami 200-lecia powstania Teatru Narodowego pojawiło się wiele opracowań poświęconych losom teatru stanisławowskiego, $z$ monumentalną rozprawą Teatr Narodowy 1765-1794 pod redakcją Jana Kotta na czele. W tej do dziś niezastapionej publikacji autor Igraszek trafu i miłości (Jeu de l'amour et du hasard) ${ }^{31}$ pojawia się wielokrotnie, gdyż był w XVIII wieku często grany, w dobrych tłumaczeniach

Ibidem, s. 43.

J. Sgard, Marivaux. Hasło w: Encyclopaedia universalis. T. 10. Paris 1971, s. 544.

Li b e ra, op. cit., s. 54. Chodzi o styl nazwany marivaudage.

31 Informację o przedstawieniu Igraszki trafu i miłości na scenie narodowej odnalazła J. Pawłow i c z o w a (Teoria i krytyka. W zb.: Teatr Narodowy 1765-1794. Red. J. Kott. Oprac. J. J a c k1 [i in.]. Warszawa 1967, s. 187-188) w „Le Journal Littéraire de Varsovie” 1777. Nie udało się ustalić autora przekładu komedii, której tytuł po polsku brzmiał Miłość sympatyczna. 
(np. Zabłockiego), w Teatrze Narodowym i teatrach prywatnych, o czym wiemy przynajmniej od momentu wydania we Lwowie w 1925 roku 2-tomowej pracy Ludwika Bernackiego Teatr, dramat i muzyka za Stanisława Augusta. Obecnie wpływami Marivaux w Polsce zajmuje się badacz młodszego pokolenia - Piotr Olkusz ${ }^{32}$.

Nazwisko Marivaux nie pojawia się w książce Klasycyzm, sentymentalizm, rokoko. Być może, zdecydowała o tym główna zasada doboru przykładów, wśród których dramaty pozostają na drugim planie. Mam jednak przeczucie, że większą przeszkoda było uznanie rokoka za prąd literacki i w związku z tym niepewna „modelowość” Marivaux w odniesieniu do tej polskiej części twórczości oświeceniowej, którą Kostkiewiczowa chce zaliczyć do rokoka.

Czy [...] jesteśmy upoważnieni do stosowania terminu „rokoko” jako nazwy odrębnego, w pełni uformowanego prądu literackiego? Wydaje się, że podstawowym czynnikiem uwydatniającym - mimo wszystkich rozbieżności i zróżnicowań - spójność zaprezentowanych tu zjawisk literackich są ich relacje wobec klasycyzmu i sentymentalizmu ${ }^{33}$.

W przestrzeni „pomiędzy” obu prądami otrzymujemy od autorki świetnie dobrane przykłady poezji, powieści (tu Rękopis znaleziony $w$ Saragossie Jana Potockiego) czy komedii (np. Zabłockiego Fircyk $w$ zalotach, o czym za chwilę). Marivaux do ram, które proponuje Kostkiewiczowa, nie pasuje. To, co zdaniem wielu predestynuje go do „sztuki prawdziwie rokokowej” (jak pisze Sgard), to nie literatura, lecz teatr, i to nie teatr klasyczny. Gdy spojrzymy na współczesne definicje rokoka, od razu rzuca się w oczy, że odnoszą się one do sztuk dekoracyjnych, malarstwa, rzeźby, architektury oraz muzyki i że są pojmowane jako ,jedna $z$ form baroku”, co pozwala np. włączyć do rokoka muzyczną twórczość obu synów Bacha, Carla Emanuela i Wilhelma Friedemanna ${ }^{34}$. W wieku XVIII skomercjalizowany teatr (tzw. antrepryza) dążąc do zapewnienia publiczności „plaisir des yeux [przyjemności wzrokowych]", poszukuje wciąż nowych form ekspresji i znajduje je w odnowionej commedia dell'arte ${ }^{35}$ oraz $\mathrm{w}$ balecie ${ }^{36}$, które sa sztukami par excellence opartymi na geście i ruchu. Marivaux wiąże się od około 1720 roku z Théâtre-Italien, który odchodzi od tradycyjnej commedia dell'arte i przez 20 lat dostarcza repertuar utrwalający sławe „osobnego” dramatopisarza. Sam fakt, że Marivaux związany był z Włochami, a nie z Comédie-Française, uznawano w środowisku paryskim za

P. Olku s z, Marivaux w osiemnastowiecznej Francji i Polsce. Dwa modele komedii dell'arte. „Pamiętnik Teatralny" 2014, z. 4.

Kostkiewiczowa, op. cit., s. 433.

Zob. Art rococo. Hasło w: Encyclopaedia universalis, t. $14\langle 1972\rangle$, s. 290, 303.

Za czasów regencji Filipa Orleańskiego komedianci włoscy, wypędzeni z Paryża za Ludwika XIV, wracają w 1716 roku, ale ich repertuar jest już grany po francusku (przedstawienia odbywają się w dawnym budynku Hôtel de Bourgogne). Théâtre-Italien (Teatr włoski) podąża równocześnie w kierunku muzycznym i tworzy z artystami z Opéra-Comique (Opery komicznej) wspólny teatr w 1762 roku. W latach 1720-1740 pierwszym autorem w Théâtre-Italien jest Marivaux. Innym autorem i aktorem Théâtre-Italien jest w tych latach np. J.-A. Romagnesi, którego sztukę przerobił na Fircyka $w$ zalotach Zabłocki. Twórczość Théâtre-Italien utrwalił na wielu obrazach J. A. Watteau, uznawany za modelowego artystę rokokowego. To te obrazy łączą w popularnej wyobraźni Théâtre-Italien $\mathrm{z}$ rokokiem.

Zob. Y. Gu es t, Le Ballet de l'opéra de Paris. Trois siècles d'histoire et de tradition. Paris 1976, rozdz. Les virtuoses du rococo. 
ekstrawagancję. To wtedy Wolter, który nie cierpiał Marivaux (przegrał z nim w roku 1742 wybory na członka Académie française), powiedział o stylu jego komedii, że ,jest jak ważenie muszych jajeczek na szalkach z pajęczyny" ${ }^{7}$, czym ustalił negatywna opinię o Marivaux w kręgach filozofów (encyklopedystów) i związał go z rokokiem, ówcześnie pojmowanym pejoratywnie, jako stylem przeciwnym regułom klasycznym bienséances (decorum).

Gdzie w polskim teatrze XVIII-wiecznym widać rokokowe wpływy Marivaux? Dobrochna Ratajczakowa w Komedii oświeconych 1752-1795 twierdzi, że u Zabłockiego, gdyż właśnie Marivaux (oprócz Beaumarchais'go) „mógł stanowić dla Zabłockiego twórczy, nowy wzór komediopisarstwa" 38 . Kostkiewiczowa natomiast uznaje - podobnie jak inni badacze - Fircyka $w$ zalotach za komedię ukazująca obraz filozofii życiowej bliskiej rokoku ${ }^{39}$. Podstawą tej argumentacji jest przede wszystkim wypowiedź Klarysy na temat rozkoszy:

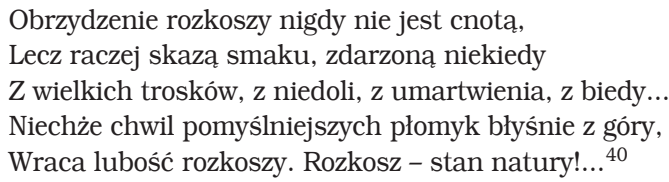

Słowa te, $n b$. pojawiające się w tekście komedii dość niespodziewanie, znajdujemy w akcie II, gdzie stanowią one część sceny 8. W swej ostatniej interpretacji Fircyka z roku 2001 Kostkiewiczowa ową „lubość rozkoszy” widzi w znacznie szerszej, już nie tylko w rokokowej, lecz także epikurejskiej perspektywie ${ }^{41}$. Wszak żaden $\mathrm{z}$ badaczy nie pokusił się dotąd o wyjaśnienie owego intrygującego sformułowania „Rozkosz - stan natury!” w kontekście współczesnych Zabłockiemu oświeceniowych idei dotyczących obyczajowości intymnej. Inaczej mówiąc: na tle encyklopedycznego hasła Jouissance. Przypomnijmy, że wzorem dla Fircyka był Petit maître amoureux (Zakochany celebryta), napisany przez Jeana-Antoine’a Romagnesiego w 1734 roku, co oczywiście wyklucza skojarzenia $z$ artykułem Jouissance Diderota, i spróbujmy naświetlić ideę „Rozkosz - stan natury!” w Fircyku w zalotach z punktu widzenia bliższego sentymentalnej ideologii mieszczańskiej niż estetyce rokoka. Redaktor Encyclopédie prezentując owo pojęcie, podkreśla od razu, że interesuje go wąski, seksualny zakres słowa „rozkosz”, ten, który w polskich słownikach XVIII-wiecznych, np. u Michała Abrahama Trotza, nazywany jest „cielesną sprawa”, a u Samuela Bogumiła Lindego „cielesnością, lubieżnością". Diderot pisze bowiem:

Rozkoszować się to poznać, doznać i odczuć korzyści posiadania. [...] Lecz zostawmy na boku owe podniebne wspaniałości, które Najwyższy stworzył dla innych niż on sam [...], i zatrzymajmy się na zmysłowości, dla której zarezerwowano słowo „rozkosz” [...]. Dlaczego czerwienisz się słysząc nazwę zmysłowości, której nie wstydzisz się, gdy odczuwasz ją w mroku nocy? Czyżbyś nie wiedział, jaki jest

Cyt. z: XVIII siècle. Éd. A. La gard e, L. Michard. Paris 1970, s. 46.

D. Ra taj c za kow a, Komedia oświeconych 1752-1795. Warszawa 1993, s. 293. Kontekst dotyczący Zabłockiego i rokoka został omówiony przez autorkę na s. 264.

Kostkiewiczowa, op. cit., s. 422.

F. Zabłocki, Fircyk w zalotach. W: Teatr, t. 3 (1995), s. 186.

T. Kostkiewiczowa, „Fircyk $w$ zalotach”. W zb.: Dramat polski. Interpretacje. Cz. 1: Od wieku XVI do Młodej Polski. Red. J. Ciechowicz, Z. Majchrowski. Wstęp, posł. D. Ratajczakowa. Gdańsk 2001, s. 90. 
jej cel i coś jej winien? Czy sądzisz, że twa matka ryzykowałaby własne życie, by dać ci twoje, gdybym [ja, natura - M. D.] jej pieszczot z małżonkiem nie wynagrodziła niewyrażalnym czarem? Zamilcz, nieszczęśniku, i pomyśl, że to owa przyjemność wydobyła cię z nicości. Rozmnażanie się istot żywych jest najwyższym celem natury. Tego domaga się $\mathrm{z}$ całą mocą od obu płci! ${ }^{42}$

W Fircyku $w$ zalotach występują dwie pary obojga płci. Postaci kobiece, Podstolina i Klarysa, mimo młodego wieku nie sa już tzw. pierwszymi naiwnymi. Obie wiedzą, czym jest związek z mężczyzną, i wypowiadają się na ten temat ze świadomością rzeczy. Wszakże w trakcie dziania się akcji komedii Zabłocki mógł powierzyć słowa odzwierciedlające ową specyficznie (seksualnie) rozumianą rozkosz tylko Klarysie. Klarysa to jedyna osoba komedii predestynowana do takiego właśnie przesłania seksualnego. Młoda, pociągająca i usatysfakcjonowana w małżeństwie z Arystem białogłowa przekazuje to przesłanie publiczności stojąc sama przed nią (scena 8 aktu II to w całości monolog Klarysy), co mogło wywołać wrażenie, iż przedstawia osobne, kobiece spojrzenie na rozkosz, czyli na swe intymne pożycie, oraz na swój „stan natury” będący konsekwencją małżeństwa ${ }^{43}$. Tutaj widzę główną różnicę w możliwym interpretowaniu przesłania autora, gdyż scena czytana w książce i scena zagrana przez żywą, młodą kobietę w teatrze to nie to samo. Apologia rozkoszy w Fircyku w zalotach, wygłoszona przez młodą mężatkę i już wkrótce matkę, o czym nas przekonuje jej mąż Aryst (akt I, scena 6: „Mam żonę, będą dziatki [...]" 44), w świetle encyklopedycznego hasła Jouissance nabiera zatem cech osobliwego przesłania ogólnoludzkiego, rzec by chyba można: przesłania humanistycznego. Rozkosz służy człowiekowi, związanym ze sobą seksualnie i społecznie przedstawicielom obu płci, determinując tym samym perspektywy całego ludzkiego rodu. Klarysa cieszy się, że istnieje taka naturalna siła. Ponieważ Klarysa pragnie, by scalała jej małżeństwo na zawsze, odrzuca wszelkie „Obrzydzenie rozkoszy”. Sprawa naturalnych fundamentów miłości kobiety i mężczyzny mogła być ważna dla samego autora Fircyka także z powodów osobistych. Przypomnijmy, że w drugiej połowie lat siedemdziesiątych XVIII wieku młody, dwudziestoparoletni Zabłocki ożenił się $\mathrm{z}$ aktorką o imieniu Katarzyna ${ }^{45}$ i choć szybko owdowiał, sentymentalne wspomnienie związku i małżeńskiego szczęścia musiało mu chyba zapaść głęboko w serce.

Sądzę, że tak naprawde jedyną na gruncie polskim bezsprzecznie rokokowa twórczością dramatyczną doby oświecenia są Parady Potockiego. Kostkiewiczowa o nich wspomina omawiając jego podróże oraz powieść Rękopis znaleziony $w$ Saragossie i nawet cytuje w przypisie fragment parady Kasander literatem. Ogólna charakterystyka Parad, która proponuje, nie zestarzała się:

D. Di d e r o t, Jouissance. Hasło w: Encyclopédie, ou Dictionnaire raisonné des sciences, des arts et des métiers. Mis en ordre et publié par D. Dider ot et quant à la partie mathématique, par J. Le Rond d'Alembert. T. 8. Langres (?) 1765, s. 889.

43 Streszczam w tym pasażu rozumowanie, które przeprowadziłem w artykule Oryginalność „Fircyka $w$ zalotach” Franciszka Zabłockiego (w zb.: W świecie myśli i wartości. Prace z historii literatury i kultury ofiarowane profesorowi Julianowi Maślance. Red. R. D ą b r ow s k i, A. W a ś k o. Kraków 2010). Warto wspomnieć, że słowo „orgazm” wchodzi do słownictwa po 1837 roku (zob. Dictionnaire de la langue française).

Zob. Łukaszewicz, op. cit., s. 15. 
Dialogi tradycyjnych postaci parad, znanych Potockiemu z terenu francuskiego, stanowia doskonały przejaw różnych typów żartu językowego, opartego zarówno na stylizacji, na semantycznych efektach bliskości dźwiękowej słów, jak też swoistym manipulowaniu ich brzmieniem dla osiagniecia komizmu. Zainteresowanie słowem, jego budową, sposobem artykulacji, akcentowanie „chwiejności znaczeniowej” wyrazów i dostrzeżenie w tym zakresie ciekawych możliwości efektu literackiego to istotne elementy charakterystyki Potockiego jako pisarza ${ }^{46}$.

O Paradach Potockiego - pomimo ich ówczesnego wystawiania na scenach i w Teatrze Telewizji - nie wiedziano jednak za wiele w latach siedemdziesiatych wieku XX. Pierwszy artykuł naukowy poświęcony związkom Parad z tego samego typu twórczością dworską we Francji oraz analizie różnych zabiegów literackich autora (o wiele subtelniejszych niż u Francuzów) został opublikowany w $1981 \mathrm{roku}^{47}$. Od tamtego czasu wiedza na temat Parad Potockiego bardzo się pogłębiła. W roku 2014 wyszła drukiem ksiażka Jean Potocki et le théâtre polonais. Entre Lumières et premier romantisme $e^{48}$, której celem było ogarnięcie wieloaspektowości tych zabawnych tekstów i wykazanie ich głębokiego znaczenia dla kultury teatralnej Europy schyłku oświecenia. Jeden drobny przykład: Pigmalion Jeana-Jacques'a Rousseau (w Polsce tłumaczył go Kajetan Węgierski), święcący triumfy na europejskich scenach (także w Warszawie), został przez Potockiego poddany pastiszowej przeróbce i zaproponowany publiczności w Łańcucie jako jednoaktówka Mieszczanin aktorem. Dzięki temu tekstowi przekonujemy się, z jaką werwą, finezją i równocześnie krytycznym dystansem podchodził hrabia Potocki do wielbionego na dworach twórcy sentymentalizmu europejskiego.

Potocki - jak wiadomo - zadedykował tomik Parad, wydany w roku 1793 w Warszawie w jego drukarni Imprimérie libre, bratowej Sewerynowej Potockiej z książąt Sapiehów, która grała w sztuce rolę Zerzabelli: „Pani! Łaskawość, z jaką zechciałaś zniżyć Twój talent ku tym ekstrawagancjom dramatycznym, ośmiela mnie złożyć Ci je w darze" 49 . Nie mógł wiedzieć tego, co około 1830 roku powie na temat rokoka Victor Hugo: „Rokoko jest znośne tylko pod warunkiem, że jest ekstrawaganckie"50. Gdyby zaś Hugo znał Parady Potockiego, byłby pewnie dla XVIII-wiecznego rokoka o wiele bardziej pobłażliwy.

\author{
Abstract \\ MAREK DĘBOWSKI Jagiellonian University, Cracow \\ ORCID: 0000-0002-4933-1818 \\ VOLTAIRE, DIDEROT, MARIVAUX, \\ OR CLASSICISM, SENTIMENTALISM, AND ROCOCO IN THEATRE
}

In Teresa Kostkiewiczowa's probably most recognised book Klasycyzm, sentymentalizm, rokoko (Classicism, Sentimentalism, Rococo) playwriting is illustrated by a small number of examples that picture

Kostkiewiczowa, Klasycyzm, sentymentalizm, rokoko, s. 401.

Zob. M. D ę b ow s ki, Oryginalność „Parad” Jana Potockiego. „Przegląd Humanistyczny” 1981, nr 3. M. D ę b o w s ki, Jean Potocki et le théâtre polonais. Entre Lumières et premier romantisme. Paris 2014.

J. Pot ocki, Parady. Przeł. J. Modrzejew ski. „Dialog” 1958, nr 8, s. 7.

Cyt. z: Rococo. Hasło w: Le Petit Robert. Dictionnaire de la langue française. Paris 1989, s. 1724. 
the shaping and qualitative changes in the functioning of the Polish Enlightened literature, while a theatrological view, namely the fortune of the classical, sentimental or rococo performances, is not the purpose. As a result, the author of the article attempts to pay attention to the playwriters whose pieces, on the one hand, were staged for Polish audience in capital theatre and in the province, and, on the other hand, to the playwriters themselves who until this day are seen as the representatives of the three main $18^{\text {th }} \mathrm{c}$. literary-artistic trends. Such an approach allows to place new accents in the considerations about the usability of the terms that we employ when classifying the then theatrical production. 